\title{
Melioidosis in Northeastern State of Malaysia: Spatial Analysis of Cases and Sequence Types
}

\author{
Adib, S. M. M., ${ }^{1}$ Harun, A., ${ }^{2}$ Ismail, A. F. ${ }^{3 *}$ and Aziah, I. ${ }^{4 *}$ \\ ${ }^{1}$ Institute for Research in Molecular Medicine, Universiti Sains Malaysia, Malaysia \\ E-mail: munirahadb@gmail.com \\ ${ }^{2}$ Department of Medical Microbiology and Parasitlogy, School of Medical Sciences, Universiti Sains \\ Malaysia, Malaysia E-mail: azian@usm.my \\ ${ }^{3}$ Department of Community Medicine, School of Medical Sciences, Universiti Sains Malaysia, Malaysia \\ E-mail: afilza@usm.my \\ ${ }^{4}$ Institute for Research in Molecular Medicine, Universiti Sains Malaysia, Malaysia \\ E-mail: aziahismail@usm.my \\ *Corresponding authors
}

DOI: https://doi.org/10.52939/ijg.v17i5.2005

\begin{abstract}
Melioidosis is caused by Burkholderia pseudomallei which can be found in water and soil, as well as in animals. This study was carried out to study the spatial distributions of the cases and their sequence types (ST) from the isolates. The cases were taken from the Hospital USM admission records from the years 2014 to 2019. There were 70 cases which from these cases 33 bacterial isolates were included in this study. Multilocus Sequence Typing (MLST) was performed to the isolates. As the results, six novel STs were discovered. The cases were found to be clustered and concentrated in the northern part of the state. This study had revealed 15 different STs however, the predominant variant, ST371 ( $n=6)$ were found to be distributed in a dispersed manner. Meanwhile, the novel STs were found distributed sporadically in few districts of the state.
\end{abstract}

\section{INTRODUCTION}

Melioidosis is a highly pathogenic infectious tropical disease caused by soil-dwelling Gramnegative bacilli named Burkholderia pseudomallei and commonly found in rice paddy fields, ponds, stagnant streams and ground water (Baker et al., 2011). B. pseudomalle $i$ is known to have the ability to survive wide range of conditions and withstand the extreme environments. Melioidosis, also known as Whitmore's disease, was identified as a remarkable imitator and maladies mimicker (Vidyalakshmi et al., 2012). Its ability to resemble other pyogenic bacterial and Gram-negative bacterial infection leading to the manifestation of non-specific signs and symptoms had limited the diagnosis and management of the disease (Vidyalakshmi et al., 2012 and Wiersinga et al., 2018). Melioidosis was highly transmitted through percutaneous inoculation of skin abrasion and in contact to contaminated soil and water (Limmathurotsakul et al., 2016). This infection can also be spread through the ingestion of any infected source of the bacteria and/or inhalation of aerosols during extreme weather events such as typhoon and cyclones (Chen et al., 2015 and Limmathurotsakul et al., 2016).
Melioidosis is endemic in Northern Australia and Southeast Asia such as Thailand and Malaysia. Thailand was reported to be the country with highest melioidosis cases compared to others (Prakash et al., 2014). The expected worldwide incidence of melioidosis occurrence is reported as 165,000 cases per year with the predicted annual mortality of up to $54 \%$. However, only less than $1 \%$ was eventually reported reflecting the burden of underreported and underdiagnosed of this neglected tropical disease worldwide (Pumpuang et al., 2017). Melioidosis in recent years increases in reported sporadic cases in countries such as Middle Eastern, Central and South American and African countries (Chakravorty and Heath, 2019). Mortality rate of melioidosis worldwide is approximately to $40 \%$ however the rate can be up to $90 \%$ if remain untreated (Wiersinga et al., 2018). Due to lack of awareness among people especially the medical practitioners had led to late diagnosis and delayed treatment therefore high mortality was reported. Annual incidence and fatality rate was highest in Northeast Thailand while melioidosis was reported as the fifth main cause of death in Singapore (Hinjoy et al., 2018 and Liu et al., 2015). 
Melioidosis has been reported since 1913 and became one of the endemic diseases in Malaysia. The incidence of the melioidosis in states of Malaysia varies but six states had been recognized with higher melioidosis cases including Kedah, Kelantan, Pahang, Johor, Sabah and Sarawak (Nathan et al., 2018). In Northeast Malaysia, 73.3\% of patients with melioidosis infection were known to be in contact with soil during working and more than 2000 patients die per year in Malaysia due to the infection (Yazid et al., 2017 and Nathan et al., 2018).

Even though melioidosis is endemic in Malaysia, there is paucity on the epidemiological data between the states including Kelantan. To date, no clear distribution of melioidosis infection was reported so far in Malaysia. Moreover, studies on the profiling of B. pseudomallei strains and their distribution among the population is important in the surveillance of melioidosis in Malaysia.

\section{Objectives}

It was postulated that the environments of the patients are related to the source of melioidosis infection and were favorable to certain types of $B$. pseudomallei strains. Therefore, the objectives of this study were to demonstrate the spatial distribution of melioidosis cases in Kelantan from the years 2014 to 2019 and to determine the sequence types of $B$. pseudomallei isolates in Kelantan and their spatial distribution. Distribution of the B. pseudomallei is important for the development of melioidosis risk map in the state in which will help in the preventive and management plan of the disease.

\section{Methodology}

This study was conducted retrospectively with confirmed cases in Hospital USM from the years 2014 to 2019 among the patients residing in the districts of Kelantan. The patients' demographic data were accessed and included in this study. The coordinates for geographical information system (GIS) were pointed to cases' residential addresses. For sequence type (ST) determination, genotyping using multi-locus sequence typing (MLST) method targeting seven housekeeping genes were performed. Only 33 isolates out of 70 samples were undergone genotyping as the remaining samples were not feasible for isolates sequencing due to the inviable bacteria in the samples. Sequences of the seven housekeeping genes were appended to form concatenated sequences using BioEdit Sequence Alignment Editor v7.2.6 software. Allelic profiles and ST of the isolates were obtained from MLST database known as Public Database for Molecular Diversity and Microbial Genome Diversity (PubMLST) for B. pseudomallei. New allelic profiles of novel STs were submitted to curator to assign for new ST number. Predominant STs of $B$. pseudomallei isolates were determined. Spatial analyses of the cases and sequence types were performed to determine their spatial distribution. The nearest neighbor ratio (NNR) analyses were also performed to determine the clustering pattern of the cases and sequence types. Meanwhile, the risk map of melioidosis in Kelantan were determined based on the hot spot area. All spatial analyses were done using ArcGIS 10.2 licensed to USM.

\section{Results and Discussion}

\subsection{Demographic Characteristics}

In this study, majority of infected patients were male compared to female thus revealing that male at higher risk for melioidosis. This is due to the nature of job in the field among male which involved farming and livestock which facilitate the exposure to environments (Wiersinga et al., 2018 and White, 2003). The highest incidence of melioidosis was reported in 48-63 years old (middle-aged group) patients followed by 15-47 years old (young-aged group). These age groups were highly involved in the agricultural and outdoor activities. Older group age was known to have poor immune response compared to other younger group (Puthucheary, 2009). Comorbidities such as diabetes mellitus and hypertension were also most likely started to develop among this age group thus became highly vulnerable for the infection (Deris et al., 2010). Three unknown age $(4.3 \%)$ was reported due to the unavailable data from the patients' records. Almost all of the cases were Malay ethnic since the majority of the Kelantan population is Malay ethnic (Sathian and Ngeow, 2014). Demographic characteristics of the cases is shown in Table 1.

\subsection{Distribution of the Cases}

Cases of melioidosis in Kelantan were highly reported in the northern part of Kelantan, namely in Kota Bharu (37.1\%) and Bachok (27.1\%) as shown in Table 2. Both districts are known to have higher density of population with high agricultural activities resulting in the high exposure to soil as melioidosis is identified to be transmitted mainly from environments (Nathan et al., 2018 and Corkeron et al., 2010). Spatial analysis of the cases showed that melioidosis were clustered with Nearest Neighbor Ratio (NNR) 0.852672, z-score 20374899 and p-value 0.017554 (Figures 1 and 2). 
Table 1: Demographic characteristics of melioidosis cases $(n=70)$

\begin{tabular}{|l|l|}
\hline \multicolumn{1}{|l|}{ Variables } & Frequency (\%) \\
\hline Gender & $53(75.7)$ \\
\hline Male & $17(24.3)$ \\
\hline Female & $6(8.6)$ \\
\hline Age group & $22(31.4)$ \\
\hline $0-14$ years old (pediatric) & $23(32.9)$ \\
\hline 15-47 years old (young) & $16(22.9)$ \\
\hline 48-63 years old (middle) & $3(4.3)$ \\
\hline$>63$ years old (elderly) & $69(98.6)$ \\
\hline Unknown & $1(1.4)$ \\
\hline Ethnicity
\end{tabular}

Table 2: Distribution of melioidosis cases according to district $(n=70)$

\begin{tabular}{|l|l|}
\hline District & n (\%) \\
\hline Kota Bharu & $26(37.1)$ \\
\hline Bachok & $19(27.1)$ \\
\hline Pasir Puteh & $12(17.1)$ \\
\hline Pasir Mas & $6(8.6)$ \\
\hline Tumpat & $2(2.9)$ \\
\hline Tanah Merah & $1(1.4)$ \\
\hline Kuala Krai & $1(1.4)$ \\
\hline Machang & $3(4.3)$ \\
\hline
\end{tabular}

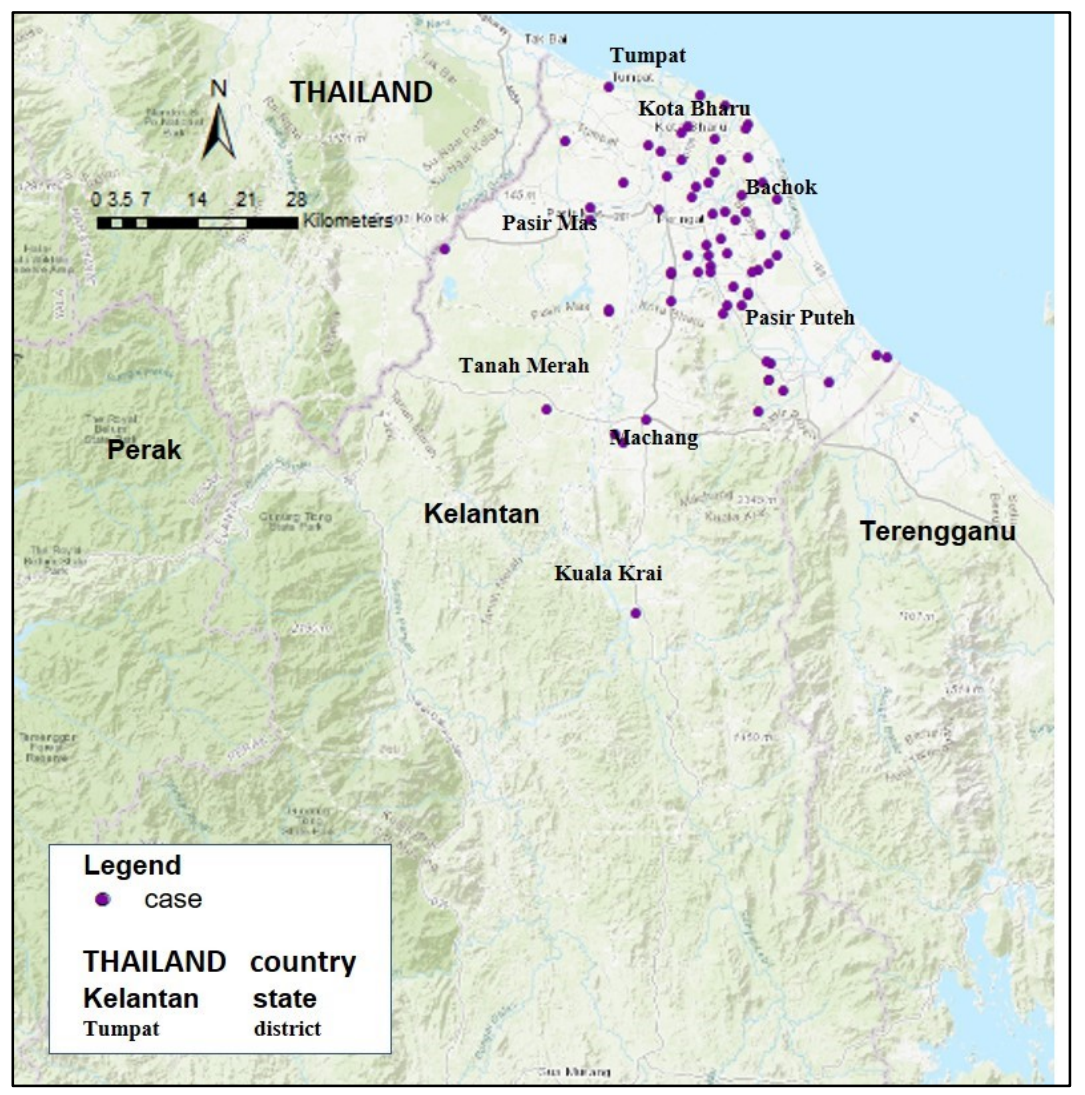

Figure 1: Distribution of melioidosis cases in Kelantan $(n=70)$ 


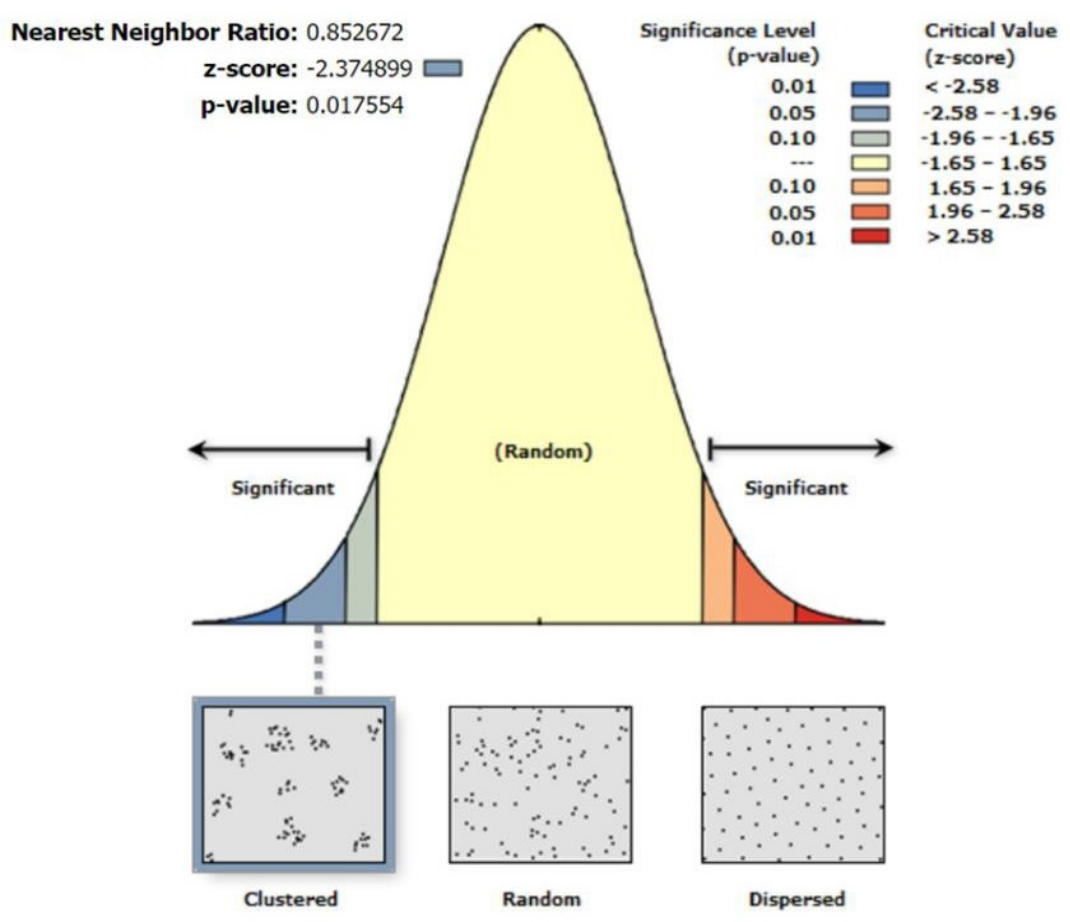

Figure 2: Nearest Neighbor Ratio (NNR) for distribution of melioidosis cases in Kelantan ( $\mathrm{n}=70)$

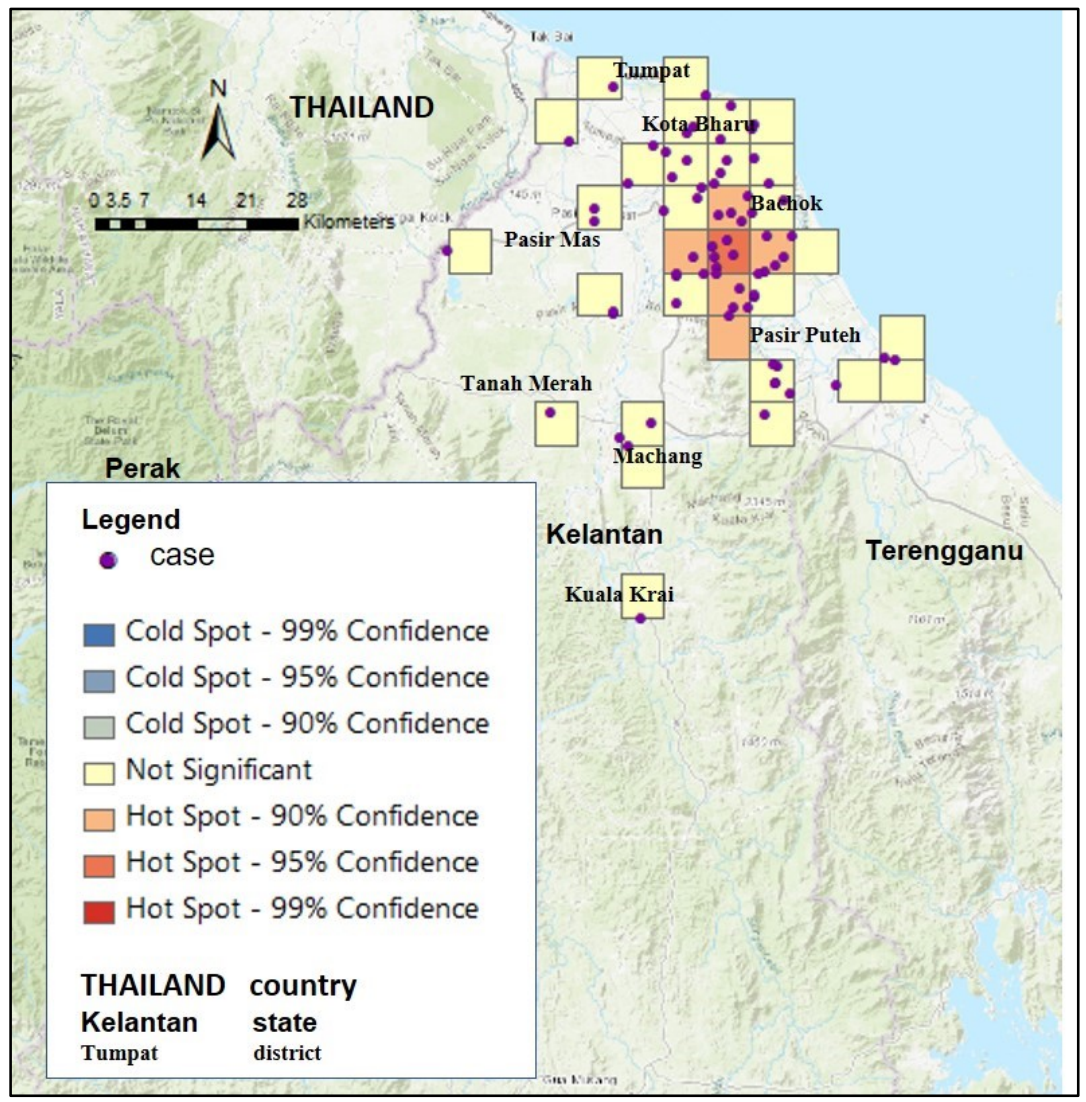

Figure 3: Hotspot area of melioidosis cases in Kelantan $(\mathrm{n}=70)$ 
It means, cases occurred with $95 \%$ probability that they were in clustered manner. In an infectious disease, the manner of distribution is important in applying action of control. Melioidosis cases in Kelantan also found to have hotspot which concentrated at Kota Bahru district with $90 \%$ to 95\% confidence (Figure 3). Therefore, people presenting with symptoms of bacterial infection from this hotspot area must be taken extra caution and need to be tested for melioidosis.

\subsection{Distribution of Sequence Types (ST)}

Multi-locus sequence typing (MLST) was conducted from the samples, however only 33 isolates were able to be obtained from the 70 reported cases. Analysis of the 33 isolates of $B$. pseudomallei in this study had found 15 STs. Seven of them were novel ST namely ST1731 to ST1737. Other eight STs which were identified as ST10, ST50, ST54, ST84, ST289, ST366, ST371 and ST414 were already reported in previous studies (Table 3). This finding indicates that the $B$. pseudomallei isolates circulating in the districts of Kelantan were genetically diverse and heterogenous. The emergence of novel STs in the population shows the ability of the bacteria to establish new clones by series of mutation processes and remain persist in the environment. All the variants were closely related and previously isolated from Southeast Asia such as Thailand, Singapore and Vietnam including Malaysia.
Figure 4 shows the spatial distribution of the STs throughout the state. Bachok, with 9 different STs, was identified as the highest district with STs variability followed by Kota Bharu and Pasir Puteh with both reported with 7 different STs. ST366 was found unique in Bachok and not isolated in other districts. Novel variants were highly found in Bachok with 3 different STs (ST1731, ST1733 and ST1735). Spatially, the novel ST found sporadically in few districts namely Bachok, Pasir Puteh, Kota Bharu and Tanah Merah (Figure 5). The predominant variant found in this study was ST371 (17.1\%). This variant was only found and isolated in districts of Kota Bharu and Bachok. Interestingly, ST371 was found to be unique for Kelantan and was not isolated in other geographical area of other previous studies in Malaysia (Arushothy et al., 2020 and Zueter et al., 2018). The predominance of genotypes in the area was suggested due to the favourable environmental condition and ecological factors such as soil types and composition, surrounding temperature and $\mathrm{pH}$ that contribute to the persistence of the strains. The soil properties and ecological niche should be one confounding factor to be included in future to correlate with the sequence types. Sequence types are found dispersed in this study, even the predominant ST (ST371) also found dispersed with NNR 2.225159, z-score 5.741152 and p-value $<0.001$ (Figures 6 and 7). Other study done in larger scale may show multiple hotspot of STs (Rachlin et al., 2020).

Table 3: Sequence types and total isolates of B. pseudomallei based on districts and reported countries $(\mathrm{n}=33)$

\begin{tabular}{|l|l|l|l|}
\hline $\begin{array}{c}\text { Sequence } \\
\text { Type (ST) }\end{array}$ & $\begin{array}{c}\text { Total } \\
\text { isolate }\end{array}$ & \multicolumn{1}{c|}{ District } & \multicolumn{1}{c|}{ Reported Country } \\
\hline ST10 & 2 & Pasir Puteh, Kota Bharu & Thailand, Malaysia \\
\hline ST50 & 3 & Kota Bharu, Bachok & Malaysia, Thailand, China, Singapore \\
\hline ST54 & 5 & $\begin{array}{l}\text { Pasir Puteh, Kota Bharu, Bachok, } \\
\text { Tumpat }\end{array}$ & $\begin{array}{l}\text { Thailand, Malaysia, Singapore, United } \\
\text { Kingdom }\end{array}$ \\
\hline ST84 & 3 & Pasir Puteh, Kota Bharu & Australia, Thailand, Malaysia, Singapore \\
\hline ST289 & 3 & Pasir Puteh, Kota Bharu, Bachok & Thailand, Malaysia, Singapore \\
\hline ST366 & 2 & Bachok & Thailand, Malaysia, Vietnam, China \\
\hline ST371 & 6 & Kota Bharu, Bachok & Thailand, Malaysia \\
\hline ST414 & 2 & Pasir Puteh, Bachok & Thailand, Malaysia, Singapore, France \\
\hline ST1731 & 1 & Bachok & Malaysia (in this study) \\
\hline ST1732 & 1 & Pasir Puteh & Malaysia (in this study) \\
\hline ST1733 & 1 & Bachok & Malaysia (in this study) \\
\hline ST1734 & 1 & Pasir Puteh & Malaysia (in this study) \\
\hline ST1735 & 1 & Bachok & Malaysia (in this study) \\
\hline ST1736 & 1 & Tanah Merah & Malaysia (in this study) \\
\hline ST1737 & 1 & Kota Bharu & Malaysia (in this study) \\
\hline
\end{tabular}




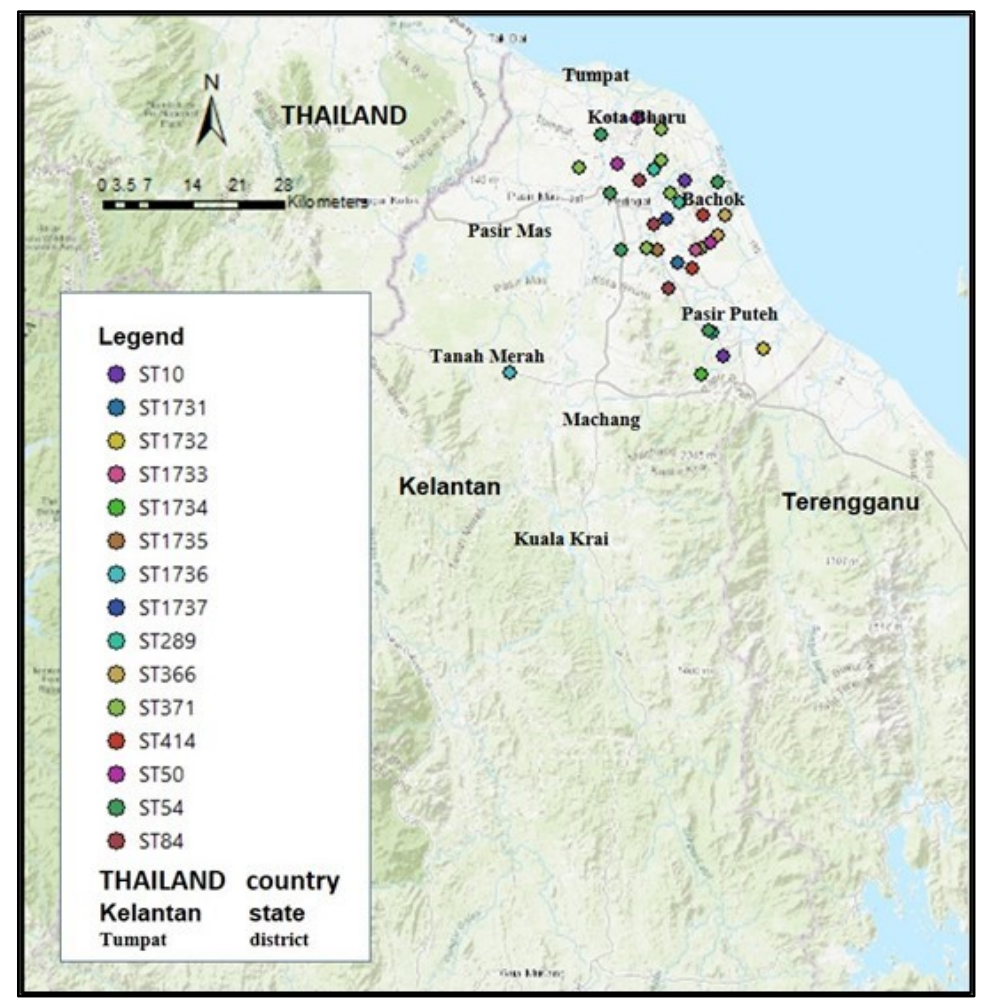

Figure 4: Distribution of STs of B. pseudomallei in Kelantan $(\mathrm{n}=33)$

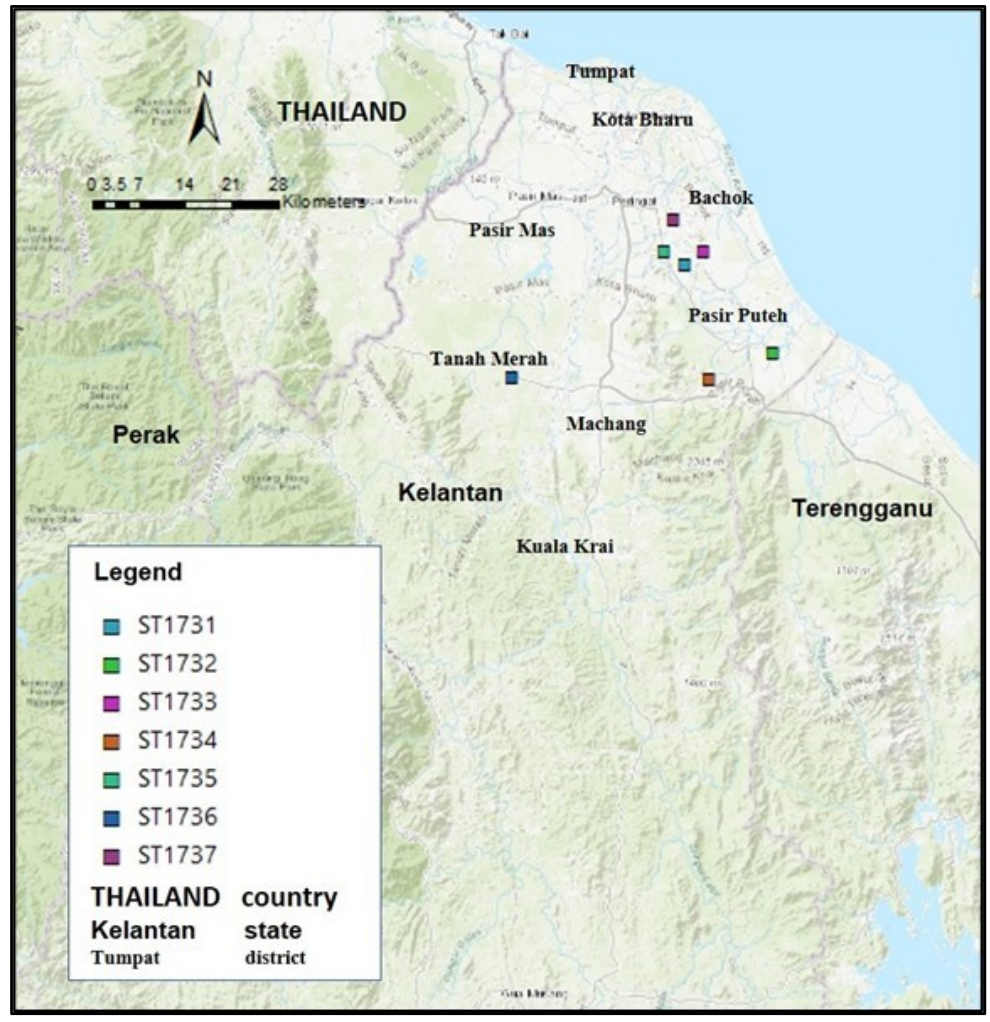

Figure 5: Distribution of novel STs isolated in Kelantan $(n=7)$ 


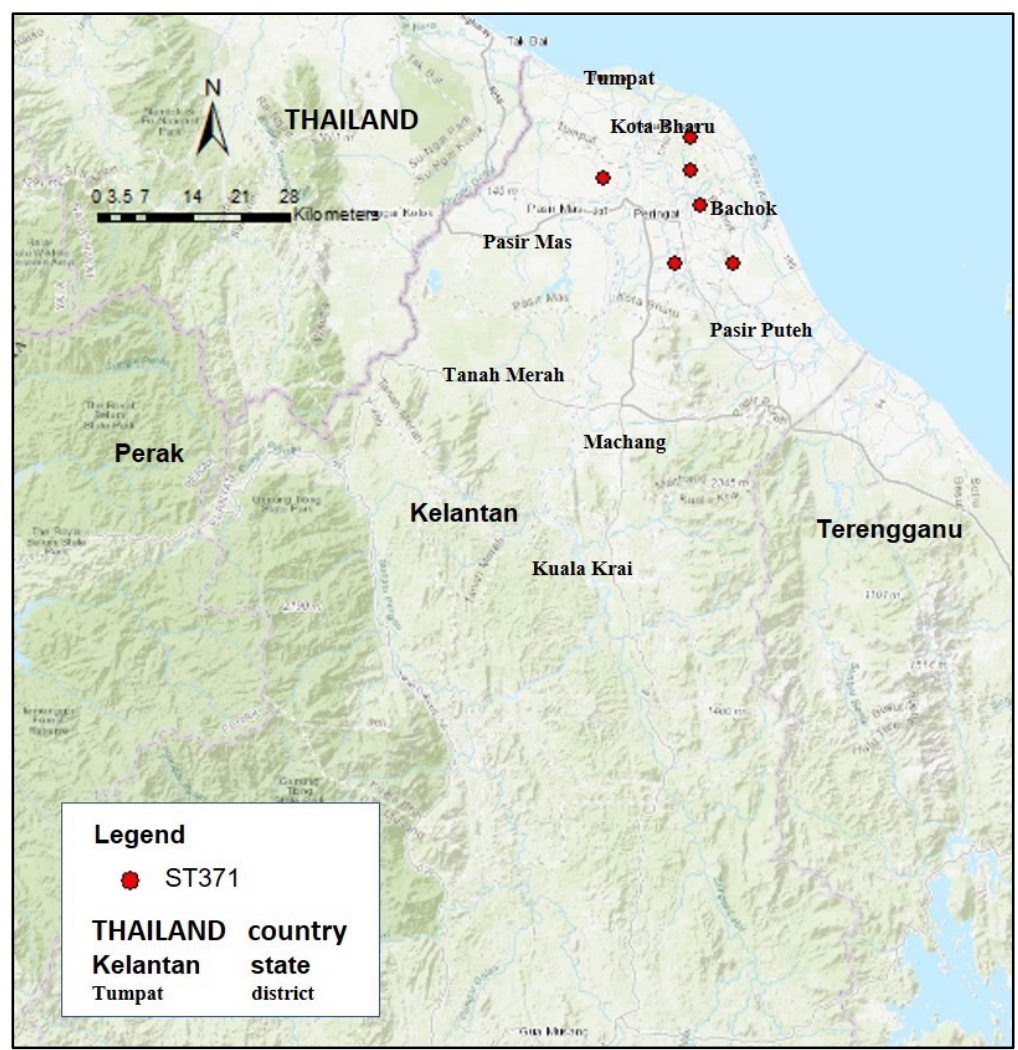

Figure 6: Distribution of predominant isolate ST371 in Kelantan $(n=6)$

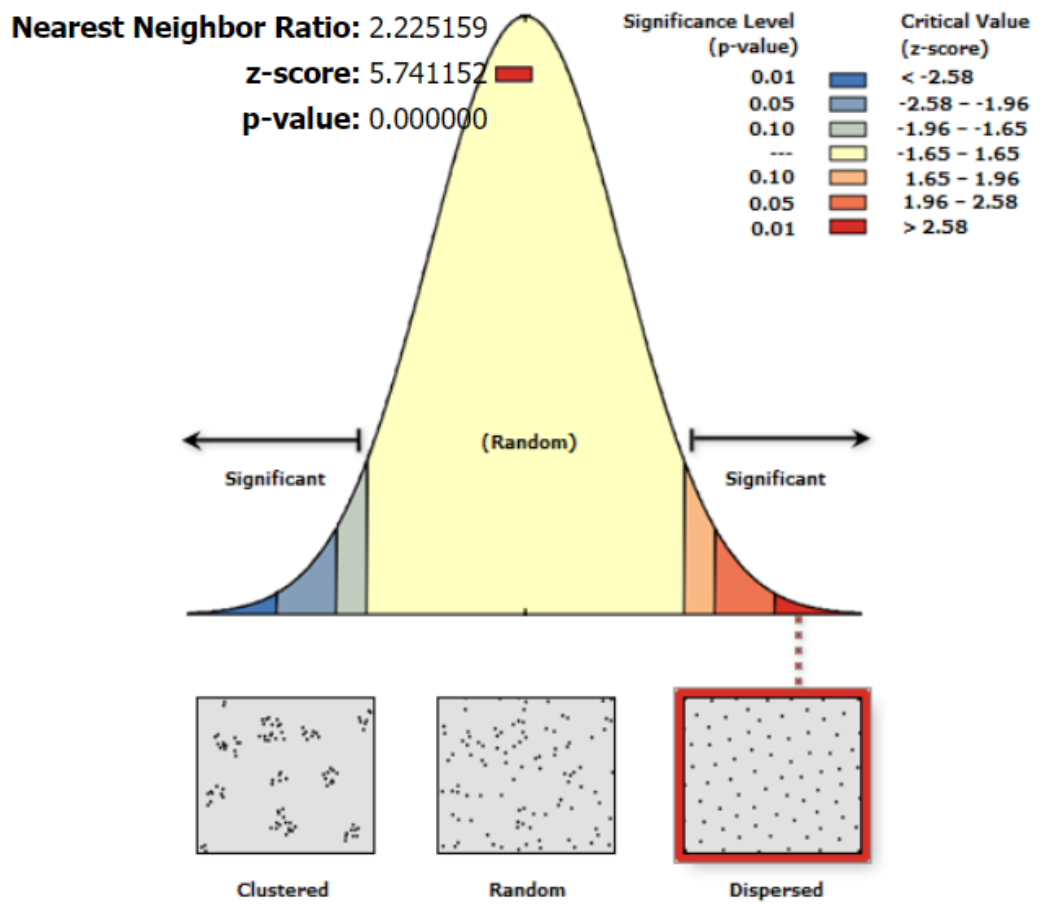

Figure 7: Nearest Neighbor Ratio (NNR) for distribution of predominant isolate ST371 in Kelantan (n=6) 


\section{Conclusion}

Melioidosis cases in the state of Kelantan in general were clustering in nature and concentrated in the northern part with Kota Bharu as the hotspot area of melioidosis. Novel STs were found sporadic in districts. However, Bachok district has the highest variability and most novel STs. The novel STs may cause more severe infection compared to other STs, therefore cases of melioidosis from this area need to be given extra caution when being diagnosed. However, further study to confirm the severity should be conducted. Variety of B. pseudomallei strains revealed to be circulating in Kelantan and dispersed in the district were important to formulate a management plan of melioidosis in future. Therefore, better preventive plan can be further applied for faster diagnosis and better prognosis especially in case of any outbreak of the disease.

\section{Acknowledgement}

This study was funded by Universiti Sains Malaysia Research University Grants (RUI) (1001/CIPPM/8012207). We would like to acknowledge Hospital Universiti Sains Malaysia and Department of Medical Microbiology and Parasitology, School of Medical Sciences, Universiti Sains Malaysia for providing the melioidosis data and bacterial isolates for this study.

\section{References}

Arushothy, R., Amran, F., Samsuddin, N., Ahmad, N. and Nathan, S., 2020, Multi Locus Sequence Typing of Clinical Burkholderia Pseudomallei Isolates from Malaysia. PLOS Neglected Tropical Diseases, Vol. 14(12), 1-14, doi: 10.1371/journal.pntd.0008979.

Baker, A., Tahani, D., Gardiner, C., Bristow, K. L., Greenhill, A. R. and Warner, J., 2011, Groundwater Seeps Facilitate Exposure to Burkholderia Pseudomallei. Applied and Environmental Microbiology, Vol. 77(20), 72437246.

Chen, P. S., Chen, Y. S., Lin, H. H., Liu, P. J., Ni, W. F., Hsueh, P. T., Liang, S. H., Chen, C. and Chen, Y. L. 2015, Airborne Transmission of Melioidosis to Humans From Environmental Aerosols Contaminated with B. Pseudomallei. PLoS Neglected Tropical Diseases, Vol. 9(6), 116.

Chakravorty, A. and Heath, C. H., 2019, Melioidosis: an Updated Review. Australian Journal of General Practice, Vol. 48(5), 327332.
Corkeron, M. L., Norton, R. and Nelson, P. N., 2010, Spatial Analysis of Melioidosis Distribution in a Suburban area. Epidemiology and Infection. Epidemiol Infect, Vol. 138(9), 1346-1352.

Deris, Z. Z., Hasan, H. and Suraiya, M. N. S., 2010, Clinical Characteristics and Outcomes of Bacteraemic Melioidosis in a Teaching Hospital In a Northeastern State of Malaysia: a Five-Year Review. The Journal of Infection in Developing Countries, Vol. 4(07), 430-435.

Hinjoy, S., Hantrakun, V., Kongyu, S., Kaewrakmuk, J., Wangrangsimakul, T., Jitsuronk, S., Saengchun, W., Bhengsri, S., Akarachotpong, T., Thamthitiwat, S., Sangwichian, O., Anunnatsiri, S., Sermswan, R. W., Lertmemongkolchai, G., Tharinjaroen, C. S., Preechasuth, K., Udpaun, R., Chuensombut, P., Waranyasirikul, N., Anudit, C., Narenpitak, S., Jutrakul, Y., Teparrukkul, P., Teerawattanasook, N., Thanvisej, K., Suphan, A., Sukbut, P., Ploddi, K., Sirichotirat, P., Chiewchanyon, B., Rukseree, K., Hongsuwan, M., Wongsuwan, G., Sunthornsut, P., Wuthiekanun, V., Sachaphimukh, S., Wannapinij, P., Chierakul, W., Chewapreecha, C., Thaipadungpanit, J., Chantratita, N., Korbsrisate, S., Taunyok, A., Dunachie, S., Palittapongarnpim, P., Sirisinha, S., Kitphati, R., Iamsirithaworn, S., Chaowagul, W., Chetchotisak, P., Whistler, T., Wongratanacheewin, S. and Limmathurotsakul, D., 2018, Melioidosis in Thailand: Present and Future. Trop Med Infect Dis, Vol. 3(2), 1-16, doi: 10.3390/tropicalmed3020038.

Limmathurotsakul, D., Golding, N., Dance, D. A. B., Messina, J. P., Pigott, D. M., Moyes, C. L., Rolim, D. B., Bertherat, E., Day, N. P. J., Peacock, S. J. and Hay, S. I., 2016, Predicted Global Distribution of Burkholderia Pseudomallei and Burden of Melioidosis. Nature Microbiology, Vol. 1(1), 1-5, doi: 10.1038/nmicrobiol.2015.8.

Liu, X., Pang, L., Sim, S. H., Goh, K. T., Ravikumar, S., Win, M. S., Tan, G., Cook, A. R., Fisher, D. and Chai, L. Y. A., 2015, Association of Melioidosis Incidence with Rainfall And Humidity, Singapore, 2003-2012. Emerging Infectious Diseases, Vol. 21(1), 159 162. 
Nathan, S., Chieng, S., Kingsley, P. V., Mohan, A., Podin, Y., Ooi, M. H., Mariappan, V., Vellasamy, K. M., Vadivelu, J., Daim, S. and How, S. H., 2018, Melioidosis in Malaysia: Incidence, Clinical Challenges, and Advances in Understanding Pathogenesis. Tropical Medicine and Infectious Disease. Vol. 3(1). https://doi.org/10.3390/tropicalmed3010025.

Prakash, A., Thavaselvam, D., Kumar, Ashu, Kumar, Ajith, Arora, S., Tiwari, S., Barua, A. and Sathyaseelan, K., 2014, Isolation, Identification and Characterization of Burkholderia Pseudomallei from Soil of Coastal Region of India. SpringerPlus, Vol. 3(1), 1-10.

Pumpuang, A., Dunachie, S. J., Phokrai, P., Jenjaroen, K., Sintiprungrat, K., Boonsilp, S., Brett, P. J., Burtnick, M. N. and Chantratita, N., 2017, Comparison of O-polysaccharide and Hemolysin Co-Regulated Protein as Target Antigens for Serodiagnosis of Melioidosis. PLoS Neglected Tropical Diseases, Vol. 11(3), 1-20. DOI:10.1371/journal.pntd.0005499.

Puthucheary, S. D., 2009, Melioidosis in Malaysia. Medical Journal of Malaysia, Vol. 64(4), 266274.

Rachlin, A., Mayo, M., Webb, J. R., Kleinecke, M., Rigas, V., Harrington, G., Currie, B. J. and Kaestli, M. 2020, Whole-genome Sequencing of Burkholderia Pseudomallei from an Urban Melioidosis Hot Spot Reveals a Fine-Scale Population Structure and Localised Spatial Clustering in the Environment. Scientific Reports, Vol. 10(1), DOI:10.1038/s41598-02062300-8.
Sathian, M. and Ngeow, Y., 2014, Essentialising Ethnic and State Identities: Strategic Adaptations of Ethnic Chinese in Kelantan, Malaysia. Asian Studies Review, Vol. 38(3), DOI:10.1080/10357823.2014.936361.

Vidyalakshmi, K., Lipika, S., Vishal, S., Damodar, S. and Chakrapani, M., 2012, Emerging ClinicoEpidemiological Trends in Melioidosis: Analysis of 95 cases from Western Coastal India. International Journal of Infectious Diseases, Vol. 16(7), 491-497., DOI: 10.1016/j.ijid.2012.02 .012 .

White, N. J., 2003, Melioidosis. Lancet, Vol. 361(9370), 1715-1722.

Wiersinga, W. J., Virk, H. S., Torres, A. G., Currie, B. J., Peacock, S. J., Dance, D. A. B. and Limmathurotsakul, D., 2018, Melioidosis. Nature Reviews Disease Primers, Vol. 4, 17107 - 17107.

Yazid, M. B., Fauzi, M. H., Hasan, H., Noh, A. Y. M. and Deris, Z. Z., 2017, An 11-Year Analysis of Emergency Presentations of Melioidosis in Northeastern Malaysia. Journal of Immigrant and Minority Health, Vol. 19(3), 774-777.

Zueter, A. R., Rahman, Z. A., Abumarzouq, M. and Harun, A., 2018, Multilocus Sequence Types of Clinical Burkholderia Pseudomallei Isolates from Peninsular Malaysia and their Associations with Disease Outcomes. BMC Infectious Diseases, Vol. 18(1), 1-10. DOI:10.1186/s12879-017-2912-9. 